\title{
THE COMMUNICATION FUNCTION COVERED IN GAN KIM YONG'S SPEECH ON RESPONSE TO CORONA VIRUS
}

\author{
${ }^{1}$ Natalia Anggrarini, ${ }^{2}$ Deuis Dian Rosdiana \\ Wiralodra University ${ }^{1,2}$ \\ E-mail: ${ }^{1}$ Natalia.anggrarini@ unwir.ac.id, ${ }^{2}$ deuis.dr@gmail.com
}

\begin{abstract}
This research deals with how the language used in communication, especially in the form of speech. It addresses to describe the criteria and categories within utterances as well as the communication function of speech. The speech acts theory used in this research is from Searle (1976). The data source of research is an English speech text addressed by Singapore Health Minister Gan Kim Yong delivered in parliament on the government's response to the coronavirus on February $3^{\text {rd }}$ 2020. This research finds the representatives with 199 utterances (73\%) as the most common speech acts which are followed by the other categories; directives in 21 utterances (13\%), commissives in 19 utterances (12\%) and expressive in 4 utterances (2\%). The analysis finds the speaker has the intention to provide sufficient information about the 2019 novel coronavirus based on the preponderance of representatives which are indicated by the use of claiming, stating, reporting, asserting, and defining utterances that provide evidence about the real circumstances happened such as data, reasons, rationale, and explanation. Thus, the belief of speaker within utterances guides the listeners for being aware of the current conditions relates to the coronavirus.
\end{abstract}

Keywords: Communication function, Speech, Speech acts, Searle's theory

\begin{abstract}
Abstrak
Penelitian ini berkaitan dengan bagaimana bahasa yang digunakan dalam komunikasi terutama dalam bentuk pidato. Ini ditujukan untuk menggambarkan kriteria dan kategori dalam ucapan serta fungsi komunikasi ucapan. Teori tindak tutur yang digunakan dalam penelitian ini adalah dari Searle (1976). Sumber data penelitian adalah teks pidato bahasa Inggris yang ditangani oleh Menteri Kesehatan Singapura Gan Kim Yong yang disampaikan di parlemen mengenai tanggapan pemerintah terhadap virus Korona pada 3 Februari 2020. Penelitian ini menemukan tindak tutur perwakilan (representative) dengan 199 ucapan (73\%) sebagai yang paling umum. Diikuti tindak tutur kategori lain; arahan (directive) dalam 21 ujaran (13\%), komisif (commisive) dalam 19 ujaran (12\%) dan ekspresif (expressive) dalam 4 ujaran (2\%). Analisis menemukan bahwa pembicara memiliki niat untuk memberikan informasi yang cukup tentang virus Korona novel 2019 berdasarkan banyaknya perwakilan yang ditunjukkan oleh penggunaan klaim, pernyataan, pelaporan, penegasan, dan pendefinisian ucapan yang memberikan bukti tentang keadaan nyata yang terjadi seperti data, alasan, dan penjelasan. Dengan demikian, kepercayaan pembicara dalam ujaran memandu pendengar untuk menyadari kondisi saat ini berkaitan dengan virus Korona.
\end{abstract}

Kata Kunci: Fungsi Komunikasi, Ujaran, Tindak Tutur, Teori Searle 


\section{INTRODUCTION}

Language is a system of communication which conveys the ideas and action through the sound or signs within. Malinowski further explains that language is the necessary means of communion; it is the one indispensable instrument for creating the ties of the moment without which unified social action is impossible. (Diamond, 1959). It means that language has the core function to communicate information of some kind or others to people. Pei (1964) states that language becomes meaningful when understood by others and the entire community decides to accept it; however, when the community changes its mind, the language symbol changes or loses its value. This condition proofs the important to produce language appropriately and consider the meaning of language wisely because it will influence the aims of communication.

One kind of communication which utilizes the necessary of language to deliver information is speech. According to Merriam Webster dictionary, speech is the communication or expression of thoughts in spoken words. Speech has various functions such as to inform people and ask them doing sure thing by following the idea of the speaker. Then speech is considered as effective communication to provide information for the public in mass. Moreover, when speech concerns with the current issue and is delivered by a reputed speaker who has an excellent position, it can grab the public attention quickly. Therefore, it is appropriate with the current condition related to the speech of Singapore Health Minister Gan Kim Yong delivered in parliament on the government's response to the coronavirus which gets much attention from the public not only Singaporeans but also the others citizen. Besides the attention, the critical thing refers to the recognition of people in order to address the function of speech itself. The recognition here begins when the speaker uses language in speech, and he produces utterance in a particular context. Then this utterance must be understood by the 
listener to deliver the intention of utterance and to achieve the recognition of speech successfully. Therefore, the utterance which refers to as a sequence of words within a single person's turn at talk that falls under a single intonation counter (Schmidt and Richards, 2002) becomes the unit of analysis of speech. So, it is crucial to analyze the language in the form of utterance to find out the meaning of speech. On account of the importance of language within speech, pragmatics takes the role to analyze what language means and used here.

According to Finch (2000), pragmatics is concerned with the meaning of utterances which has focused on what is not explicitly stated and on how people interpret utterances in a situational context. Central to pragmatics is speech act theory which was invented by Austin (1962) and developed by Searle (1969). Austin (1962) defines speech acts as acts which are performed in uttering something. In line with Austin, Flowerdew (2013) further mentions speech act is concerned with the functional, communicative and value of utterances and the using of language that performs actions such as stating, requesting, advising, and promising. In short, speech acts are the utterance that contains the meaning of acting. By analyzing the speech act theory, there will be found the meaning of speech which is built by the utterance within.

There are some researches conducted to analyze the speech in case of speech act. First, Dylgjeri (2017) finds the acceptance of nomination speeches are dominated by assertive, expressive, and commissive act. It is due to the use of speech as mobilization strategies, especially in a political campaign. Thus it is essential to persuade the listeners towards the desired goal of winning elections. Second, Hashim (2015) identifies commissive speech acts are used more than other types of speech acts which means the speakers promise and challenge the listeners to show that they are committed to the task. Third, Akinwotu (2013) mentions that the speech which contains commissive, then assertive and expressive as the most significant percentage means 
the enthusiasm, to be thankful, promising and encouraging the listener.

Most recent researches only analyze the speech in term of categories of speech acts. However, it is not found the process of why the utterances of speech differ one to another until they have their categories of speech acts. Also, the utterances used in those researches only provide some specific portions from the speeches, not the complete one, which means there is a possibility for the result will change once the complete speeches analyzed. To fill this gap, the current research attempts to identify the criteria of each utterance as the process which describes they belong to different categories of speech acts. Furthermore, the data used is the full speech, so this current research provides the reach data to analyze, which means the result reveals the full content meaning.

Under the explanation above, this current research analyzes the speech of Singapore Health Minister Gan Kim Yong by utilizing Searle (1976) theory. It is interesting to analyze this speech because it talks about the current issue, coronavirus and gain much attention from the public. On account of the necessity of finding and discussion; thus, this research has the purpose of describing the criteria and categories of speech act used and finding out the meaning of speech by Gan Kim Yong.

\section{Speech Act}

The discussion of speech acts comes from the pragmatic, which is considered as the study of language in use as stated by Flowerdew (2013) pragmatic deals with how language is used in context and the relationship between language use and language form. The other definition of pragmatics is from Finch (2000) who says that pragmatics is concerned with the meaning of utterances which has focused on what is not explicitly stated and on how people interpret utterances in a situational context. In other words, pragmatics is the study of how language is used to communicate by considering the language form, function and context. 
Then it is concerned with how people use language within a context and why they use language in particular ways. Following that, pragmatics has specific discussion fields such as speech acts, conversational implicature, the cooperative principle, politeness and relevance. In this research, the focus of pragmatics used to analyze the meaning and function of words in different speech situations is a speech act.

The term speech acts were invented by Austin (1962) and developed by Searle (1969). Austin (1962) defines speech acts as acts which are performed in uttering something. Flowerdew (2013) further mentions speech acts are concerned with the functional, communicative and value of utterances and the using of language that performs actions such as stating, requesting, inviting, and promising. In short, speech acts are the utterance that contains the meaning in acting. Accordingly, each utterance produced has its function, and it will act such as stating, requesting, inviting, and promising. Then Austin (1962) distinguishes three distinct levels of action beyond the act of utterance. First, the locutionary act deals with the act of uttering something; that refers to what was said or explicitly, the words uttered. Second, illocutionary act is the conventional force achieved in the saying of that utterance; in merely it is what was meant by the utterance. Third, perlocutionary act means the effect or influence on the feelings, thoughts or actions of the listener; it guides to what happened as a result of utterance. However, there is a different interpretation of illocutionary act between Austin (1962) and Searle (1976). It is due to according to Austin illocutionary act is the successful realization of the speaker's intention, which for Searle (1976) is a product of the listener's interpretation.

\section{Criteria of Speech Act}

Before the classification of speech act emerges, there is a necessity for distinguishing one kind of illocutionary act from another. In this case, Searle (1976) provides some criteria of variation in which 
illocutionary acts differ one from another, the main ones which are as follows:

1. Differences in the point (or purpose) of the (type of) act This criterion is also called as illocutionary point. It deals with the purpose of the speech act. In other words, the differences of speech acts correspond to the essential conditions which mean what the utterance counts for. For examples, the purpose of request can be specified by saying that it is an attempt to get the listener to do something; the purpose of a description is that it is a representation (true or false, accurate or inaccurate) of how something is; the purpose of a promise is that it is an undertaking of an obligation by the speaker to do something.

2. Differences in the direction of fit between words and the world Direction of fit is always a consequence of illocutionary point. It means that the result or effect brought by illocutionary point influence the realization of utterance. There are two dimensions of direction of fit, which are to get the words (more strictly - their propositional content) to match the world, others to get the world to match the words. Getting the words to match the world means the speaker has an attempt to provide utterance which is appropriate with the conditions, e.g. asserting, stating, claiming, etc. Whereas, getting the worlds to match the words means the speaker has an attempt to provide condition based on the utterance produced, e.g. promising, requesting, advising etc.

3. Differences in expressed psychological states

This criterion deals with what the speaker expresses in the performance of the act. For examples; an expression of belief emerges in asserting, stating, claiming and affirming; an expression of a wish or desire emerges in requesting, ordering, commanding, praying, advising, and entreating; an expression of gratitude and pleasure emerges in 
thanking, welcoming, and congratulating.

\section{Classification of Speech Act}

Led to the different interpretation of illocutionary act with Austin, Searle (1976) then uses his own criteria to divide the speech acts into five categories as follows:

\section{Representatives}

This category deals to commit a speaker to the truth of the expressed proposition. The point is describing states or events in the world which involve these acts such as stating, reporting, defining, claiming, asserting, concluding etc. Therefore, testing the representatives can be done by merely questioning whether they can be categorized as true or false. Besides, Kreidler (1998) mentions the representatives' guide speakers using language to tell what they know or believe; that is, representatives' language is concerned with facts. Therefore, in general, the purpose is to inform.

\section{Directives}

This category deals to make another person's action fit the propositional element. The directives show an attempt by the speaker to get the listener to do something which is applied into some actions such as requesting, demanding, commanding, ordering, inviting, advising, forbidding and so on, Yule (1996) further states the directives express what the speakers want. Accordingly, the directives have the aim to get the listener do an action as the effect of utterance.

3. Commissives

This category deals to commit a speaker to some specific future actions. Yule (1996) adds the commissives relate to what the speaker intends. Further, Kreidler (1998) explains that commissive verbs are usually illustrated by agreeing, ask, offer, refuse, swear, all with following infinitives. On account of the point is that the speaker has something to do because of the utterance in the future. Then the subject of the sentence is, therefore, most likely 
to be the first-person pronoun like I or we. Also, the utterance will be considered as commissives when there is a modal will or (to be) going to (in specific rules, contexts and situation) that indicate a promise.

4. Expressives

This category deals with expressing the feeling regarding a state of affairs that the expressive refers. In other words, expressive refers to a speech act in which the speaker expresses his/her feeling and attitude about something that can be a statement of pleasure, pain, like, dislike, joy and sorrow. The examples of expressive are congratulating, apologizing, thanking, complaining, etc.

5. Declarations

This category deals with successful performance, which refers to the correspondence between the propositional content and reality. In simply, the declarations refer to kind of speech acts that changes the world via utterance. The examples of declarations are Christening or baptizing, declaring war, abdicating, resigning, dismissing, naming, and excommunicating.

\section{METHOD}

The theory of analysis in this research utilizes the linguistic approach of speech acts conveyed by Searle (1976), which focuses on two points; the criteria of classifying speech acts and categories of speech acts. Accordingly, this research has the purpose of describing the criteria and categories of speech acts used and finding out the meaning of speech by Gan Kim Yong. Therefore, the design used in this research is a qualitative content analysis which focuses on the characteristic of language as communication with attention to the content or contextual meaning of the text. (Budd, Thorp, \& Donohew, 1967; Lindkvist, 1981; McTavish \& Pirro, 1990; Tesch, 1990).

The data source of this research is an English speech text addressed by Singapore Health Minister Gan Kim Yong delivered in parliament on the government's response to the coronavirus on February $3^{\text {rd }} 2020$. The video of the 
speech was downloaded from https://www.youtube.com/watch?v=a 6KjmK_GS44. Besides the video, the researcher downloads the transcribe to help to match the expression and the speech from https://www.channelnewsasia.com/n ews/singapore/wuhan-coronavirussingapore-gan-kim-yonggovernment-response-12385478.

There are three phases in doing the study. First, collecting the data or observation by watching the video and read the script of the speech. Second, identifying the criteria and categories of speech acts produced by Singapore Health Minister Gan Kim Yong. Third, analyzing and interpreting the data by using speech acts theory from Searle.

\section{FINDINGS AND DISCUSSION}

Finding

The observation of Singapore Health Minister Gan Kim Yong's speech video provides the 163 utterances. Before the categories presented, there are criteria used for analysis which focus into three dimensions, involving illocutionary point, the direction of fit and speaker's psychology state. The utterances complete the criteria by distributing into different result, and then the classification of speech acts category is conducted. Furthermore, the categories are specified into specific types of speech acts. The results are provided into the following table below.

Table 1 Summary of Speech Act's Category

\begin{tabular}{|c|l|c|c|}
\hline No. & \multicolumn{1}{|c|}{ Acts } & Frequency & Percentage \\
\hline 1 & Representatives & 119 & $73 \%$ \\
\hline 2 & Directives & 21 & $13 \%$ \\
\hline 3 & Commissives & 19 & $12 \%$ \\
\hline 4 & Expressives & 4 & $2 \%$ \\
\hline 5 & Declarative & 0 & $0 \%$ \\
\hline \multicolumn{2}{|c|}{ Total } & $\mathbf{1 6 3}$ & $\mathbf{1 0 0 \%}$ \\
\hline
\end{tabular}




\section{Discussion}

The speech of Singapore Health Minister Gan Kim Yong delivered in parliament on the government's response to the coronavirus performs four categories of speech acts in general. In this case, the speech acts within speech are dominated by representatives with $73 \%$. Then it is followed by directives in $13 \%$, commissives in $12 \%$ and expressive in $2 \%$. The detail explanation is presented in the following discussion.

\section{Representatives}

The most common speech acts found at the speech of Gan Kim Yong is representatives. It represents $73 \%$ of the total utterance acts performed. There is a total of 119 utterances which are then specified into the particular types of representatives speech acts which are claiming, stating, reporting, asserting and defining. Each example of certain types is discussed as follow:

(U85) We had set up multiple lines of defence to reduce the risk of imported cases and local community transmission. We have been stepping up our posture and efforts at each line of defence.
(U137) If the infected Singaporean wears a mask to protect others, and promptly sees a doctor and gets triaged for testing, the risk of further spread can be greatly reduced. Even if there is spread, quick action will help to limit its extent.

The claiming utterances become the most common speech acts found which deals with the effect that what speaker says represents an actual state of affairs. In this case, the speaker commonly shares what the government has done as a measurement to combat the novel coronavirus. As presented at U85, the speaker mentions that the government has prepared multiple lines of defence to face the several possibilities of coronavirus development in case of the risk of imported cases and local community transmission. In the other side, the speaker delivers the claiming speech acts because he has belief relate to what he says. As shown at U137, the use of a mask by an infected person is considered reducing the virus spread because it can protect the healthy one. 
(U59) Wearing a mask when we well often give us a false sense of security instead, and we are more likely to touch our faces when we continuously adjust our masks, which is one way the disease spreads.

(U43) If these droplets come into contact with the eyes, nose or mouth of an individual, directly or indirectly through hands that have come into contact with these droplets, the individual may become infected.

The utterances of stating at the speech provide the information clearly and thoroughly. The examples are taken from U59 and U43. U59 states that the use of mask may spread the disease by providing its rationale. It is mentioned that there is a high possibility to touch face when constantly adjust the masks. Thus, it is hoped that the listeners recognize the appropriate function of wearing a mask. Then the speaker in U43 states clearly and fully the disease spread process from droplets which are started through hands that have come into contact with these droplets. Therefore, by receiving this information, the listener may realize the necessity to prevent touching the eyes, nose or mouth directly with hand.

(U4) On January 30th, the World Health Organization declared that the outbreak constituted a Public Health Emergency of International Concern, raising the global alert levels.

(U31) Latest WHO report showed that there were more than 14,000 reported cases in China and 304 deaths.

The reporting utterances at the speech of Singapore Health Minister Gan Kim Yong deals with the data. It means that the utterance provides an account of something done. As represented in $\mathrm{U} 4$, there is a description of what happened on January 30th, which refers to WHO declaration relate to the status of the novel coronavirus as an international concern. Then U31 presents the data of cases and deaths caused by a coronavirus in China based on WHO. These reporting utterances provide actual and accurate information about the state of affair for the listeners, so the concern about what is happening during the novel coronavirus period. 
(U66) The current approach is to provide good supportive care for the patients to reduce complications and to allow time for the patient to recover.

(U121) I would also like to emphasize that there is no need to avoid our healthcare workers during this time.

The utterance of U66 and U121 represents asserting, which means state about something firmly. The speaker underlines providing good supportive care for patients is essential, as mentioned at U66. In this case, the patients are prioritized because it may reduce the possibility of disease complication while there is no curative treatment for a novel coronavirus. This asserting utterance is supported by the previous stating speech acts which deliver the background information why this is stated firmly to prioritize the good supportive care for patients. Thus, by this asserting utterance, it reveals that the government takes this as a serious approach to combat the coronavirus. In the other side, the U121 is indicated as the asserting due to the use of emphasizing the word, which means there is particular importance given to healthcare workers. The healthcare workers here are perceived as the crucial frontline to face the period of coronavirus. Therefore, this utterance influences the listeners' recognition of the role of healthcare workers.

(U39) The virus comes from the family of coronavirus, which includes other viruses such as MERS and SARS, as well as the milder variance causing the common cold.

(U42) What this means is that the virus is carried within droplets emitted from an infected person over a short distance, such as when the person coughs or sneezes.

The last representatives' speech acts in this research is defining. In this case, the speaker still commits to something is being the case which is about the 2019 novel coronavirus. However, in defining, he tries to show clearly what is the meaning of a particular state is. For instances; U39 defines the novel coronavirus, and U42 defines the droplets transmission. The U39 presents the novel coronavirus description, involving the information about the 
type which this virus belongs to and symptom that may happen to owe to this virus. After that, the speaker in U42 explains how the transmission of coronavirus occurs through droplets and provides the examples of acts which cause the droplets. In these utterances, receiving the information guides the listeners for being aware of the transmission of a novel coronavirus, so they consider what activity they involve in daily. Furthermore, the utterances of defining speech acts are delivered at the beginning of the speech. It is considered as an excellent step to bring the listener to realize first what the speaker is talking about and the urgency of the topic discussed.

Based on Searle (1976), the point of representatives is describing states or events in the world. In general, the representatives of speech acts appear at the speech of Singapore Health Minister Gan Kim Yong focus to provide the information relates to the 2019 novel coronavirus. It is then presented explicitly through the acts of claiming, stating, reporting, asserting and defining above. This condition is caused by the direction of fit of representatives which is words to the world. It means that the speaker has an attempt to provide utterance, which is appropriate with the real circumstances that happened.

Kreidler (1998) further mentions representatives guide speakers using language to tell what they know; that is representatives language is concerned with facts. In this case, it is also found that the Singapore Health Minister Gan Kim Yong has evidence about the real circumstances happened such as reasons, rationale, explanation etc. for the development of novel coronavirus. The example of evidence that he provides at the speech involving the measurement of government, data of corona cases based on WHO, and explanation of virus transmission via droplets, etc.

Considering the evidence for a state of affairs, so the speaker's psychological state delivered here is belief. It means that the Singapore Health Minister Gan Kim Yong is the confidence to deliver the utterance based on the information 
he recognizes. In short, the speaker has a belief with what he said is true.

Accordingly, when the Singapore Health Minister Gan Kim Yong provides sufficient information, it is hoped that the Singaporean realize what is happening today as the effect of these representatives speech acts, so they have knowledge, confidence and hopefulness to combat the novel coronavirus.

\section{Directives}

The category of directives is in the second position at the Singapore Health Minister Gan Kim Yong's speech accounting for $13 \%$ of the total data for this research. It is found that there are 21 directives speech acts here which are specified into three types; requesting, advising, and demanding. To discuss the meaning of directives speech act, then these are provided with the example of utterances for each type as follow:

(U56) We should regularly wash our hands with soap and water, and avoid touching our face with our hands.
(U124) Instead, let us together, stand behind them and support them in this period

The utterance U56 and U124 are requesting. In these utterances, the speaker wants the listener to do some actions. U56 presents the action which is washing hands with soap and water, and avoid touching face with hands. In this utterance, the speaker uses we by positioning the speaker and listener at the same time. It also becomes the reason why U56 belongs to requesting, because the speaker that is Singapore Health Minister as the part of government does not show the authority here, but prefer to have some positions with the listener that refers to Singaporean. Thus, the meaning of U56 is getting all Singaporean, including government to wash their hands with soap and water, and avoid touching their face with hands.

Then the action presented for the listener in U124 is giving stand and support them in this period. The use of them here actually relates to the previous utterance, which refers to the healthcare workers. However, this utterance is allocated for all 
Singaporean, including the government as well. It is known when a speaker utters let us together, so once again, it means that the government does not indicate their authority here. Therefore, the point of U124 is to get all Singaporean, including the government, supports healthcare workers during the 2019 new coronavirus period.

(U55) As such, medical professionals both overseas and in Singapore have advised that the most effective way that we can protect ourselves is to practice good personal hygiene.

(U62) If we do need to go out to see a doctor, for example, we should wear a surgical mask to protect others. So this is when a mask is needed - when we are unwell and have to go out.

There are U55 and U66 as the sample of advising acts. The difference between a request and advise is in the sense of them. It means that advising is more than requesting because it claims that the action to do is the principal. As mentioned in Searle (1969), advising is not trying to get people to do something in the sense that requesting is and advising is more like telling people what is best for them. In other words, the speaker has some reasons to believe that the presented action will benefit the listener. In U55, the speaker gets to the listener practice good personal hygiene because this action is acknowledged by medical professionals both overseas and in Singapore, which means it is the exact and effective act to protects. It means that practising good personal hygiene is the best thing that can do to protect the listener. In another side, U62 shows the speaker believes a surgical mask is needed when we are unwell and have to go out to see a doctor because it can protect the others. So, the point of U62 is to propose Singaporeans who go out seeing a doctor wear a surgical mask to protect others.

(U129) We are not sure how long this virus will turn out. Therefore, we must stand ready to respond to new developments as the situation evolves.

(U148) Let me conclude by once again appealing to all Singaporeans to work 
together with us in this fight.

The last directives which found at the speech are demanding. In this type, the necessary to do the thing is delivered very firmly by the speaker. The speaker at U129 indicates the indispensable condition by using a must. Moreover, the speaker states the unpredictable situation at that time, which also supports the urgency to do this thing. So, the point of U129 is to ask Singaporean firmly for being ready to all any possibility of virus development. After that, the necessary condition of U148 is identified by using verb appealing, which means the speaker makes a severe and urgent request to them. Furthermore, the speaker states once again, and it indicates that this thing has been uttered previously, but it is done again, so there is a necessity to get the listener do it. Then led to those considerations, the point of $\mathrm{U} 148$ is to ask all Singaporeans firmly to work and fight the 2019 novel coronavirus together.

In general, directives shows an attempt by the speaker to get the listener to do something, as stated by Searle (1976). Based on the utterances above, the most common theme which is used by the speaker is we. The use of we here indicates the speaker does not portray himself as the one who wants the listener to do something, but we refer to the Singapore government. However, there are some conditions which make the utterance differs into some types, as mentioned before.

According to Searle (1976), directives speech act deals to make another person's action fit the propositional element. The propositional element here is that the listener does some future action. This condition reflects into its direction of fit, which is the world to words. It means that the government has an attempt to realize the condition of Singaporean to do something based on the utterance produced. The speaker's psychological state also occurs within this speech act which is desire. In short, the government has a desire to Singaporean to do some actions involving wash their hands with soap and water, avoid touching their face with hands, 
support the healthcare workers, wear a mask when sick, practice good personal hygiene and work together to fight novel coronavirus together.

The directives speech acts within the speech of Singapore Health Minister Gan Kim Yong literally delivers the government's desire to get Singaporean participants to work together in combatting the 2019 novel coronavirus. The various types of directives then are necessary to emphasize the importance to collaborate with the government. In this case, the delivery of directives speech acts is considered adequate to get the listener do various actions, because there are commonly representative speech acts first before the directives uttered. Thus, the listener is provided with the states or events description, which becomes the reasons why they should do something.

\section{Commissives}

The speech act which has the third position at the speech of Singapore Health Minister Gan Kim Yong is commissives. Commissives have $12 \%$ percentages which are emerged from 19 utterances. In this case, the commissives utterances are specified in the speech act of promising. These are the following example of utterance for commissives speech act:

(U101) With each confirmed case, we will conduct contact tracing.

(U102) We will check on the health of these contacts, and if they are unwell with fever, cough or other respiratory symptoms, they will be classified as suspected cases.

(U103) We will check on the health of these contacts, and if they are unwell with fever, cough or other respiratory symptoms, they will be classified as suspected cases.

(U104) We will arrange for them to go to the hospital via a dedicated ambulance for isolation and testing. For contacts that are well, we adopt a risk-based approach.

Before the utterances above differ into commissives, they are considered by some criteria first involving illocutionary point, the direction of fit and psychological state. In the case of illocutionary point, those utterances have the following purpose: 
(U101) To undertake the government, conduct contact tracing to the confirmed case.

(U102) To undertake the government, do check the health of people who contact with a confirmed case.

(U103) To undertake the government do isolation and testing for the suspected cases

(U104) To undertake the government do quarantine for the suspected cases.

According to Searle (1976) the point or purpose of a promise is that it is an undertaking of an obligation by the speaker to do future actions. To indicate the one who takes responsibility for the future actions, Singapore Health Minister Gan Kim Yong as the speaker uses we that refers to the government side who are helped by the healthcare providers. However, it can be said that the speaker represents the government in general as the policymaker in this case to take some measurements which include the future actions appear in illocutionary point.

The future actions appear in illocutionary point relates to what the

speaker expresses, as mentioned by Searle (1976) with the speaker's psychological state. It is due to in general, in the performance of speech act with propositional content, the speaker expresses some attitude, state, etc., to that propositional content. It means that when the speaker promises to do some future actions, the speaker also expresses an intention to do so. In short, the speaker's psychological state of U101, U102, U103, and U104 is intention. Therefore, the intention of the speaker in these utterances is to convince the listeners in case of Singaporean about governments measure and efforts to do various future actions of combatting the novel coronavirus in their favour by conducting tracing to the confirmed case, checking the health of people who contact with a confirmed case, providing isolation and quarantine for the suspected cased.

The U101, U102, U103, and U104 provide an obligation of the speaker to do specific actions, and it relates to the real implementation. It means that the result or effect brought by illocutionary point 
influence the realization of utterance. This condition is acknowledged by Searle (1976), who mentions the direction of fit is always a consequence of illocutionary point. In this case, the speaker who represents the Singapore government tries getting the worlds to match the words means they have an attempt to provide condition based on the utterance produced. In other words, the government will realize the measurements as mentioned previously such as conducting tracing to the confirmed case, checking the health of people who contact with a confirmed case, providing isolation and quarantine for the suspected case to the concrete actions.

Considering the speech acts of U101, U102, U103, U104 and the others commissives at the speech of Singapore Health Minister Gan Kim Yong, the future actions refer to the measurement of government in some fields to combat the novel coronavirus. In other words, there are scenarios or preparation of government to protect the Singaporean from the threat of the virus. Led to this category deals to commit a speaker to some specific future actions, so the government here tries to ensure Singaporean that they are ready to fight the further development of virus even in the worst condition.

\section{Expressive}

The last speech acts which are found at the speech of Singapore Health Minister Gan Kim Yong are expressive. There are only four utterances which belong to expressive thus the percentage is only $2 \%$. These utterances then are specified in thanking speech acts. The following utterances are the expressive speech acts found at the speech:

(U110) I would like to extend my sincere appreciation to all our healthcare workers and their families.

(U126) I am also very encouraged by our various communityled efforts.

(U149) I am very heartened by the many examples of volunteers stepping forward to support our efforts.

(U154) I would also like to acknowledge once again our healthcare workers on the frontlines and commend 
them for their bravery and selflessness.

The four utterances above belong to the speech acts of expressive because they have similar point or purpose, which deals as an expression of gratitude or appreciation. It is shown that the speaker reveals his feeling in the form of gratitude and appreciation to the people who participate in combatting the novel coronavirus. In this case, the $I$ refers to Singapore Health Minister Gan Kim Yong, who also has a role as the representative of the Singapore government. Thus, the gratitude and appreciation here actually are granted by the government. The government here thanks to the people because they have given benefit by providing help and support, which is counted as the cooperation, and this makes the government easier to combat the virus together. Based on U110 and U154, the government thanks to the healthcare workers and their families. Then there are various community and volunteers which get the appreciation from the government in U126 and U149.
It is evident that U110, U126, U154, and U149 has no direction of fit. It is because in performing an expressive, the speaker is neither trying to get the world to match the words nor the words to match the world, rather the truth of the expressed proposition is presupposed. In this case, there is the truth that healthcare workers, various community and volunteers have contributed to help and support the government in combatting the virus. This condition is in line with Searle (1976), who states that the direction of fit is always a consequence of illocutionary point. Then for the illocutionary point of these utterances are expressing the gratitude about what have healthcare workers, various community and volunteers done. So, the speaker here only expresses the feeling regarding the efforts of healthcare workers, various community and volunteers. Furthermore, it also clearly relates to the speaker's psychological state, which presents grateful and appreciative.

Searle (1976) mentions this category deals with expressing the 
feeling regarding a state of affairs that the expressive refers. As mentioned before, the feeling of the speaker is grateful and appreciative. Then U110, U126, U154, and U149 utterances fulfil the expressive speech act by also providing state of affairs, which is an effort to combat the 2019 novel coronavirus. Even it is not stated clearly in these utterances what kind of activities that healthcare workers, various community and volunteers have done. The speaker has stated their effort previously in earlier utterances which have also been explained in the prior discussion above. So literally it is the excellent strategy of the speaker by mentioning the all what have they done first to invite the listener realizes the presented efforts and then the feeling of gratitude and appreciation is expressed to thank the healthcare workers, various community and volunteers. Therefore, it implies that the public can see the government gives the appreciation to the healthcare workers, various community and volunteers. In addition, U149 utterance is delivered nearly at the end of speech which emphasizes that government thanks to the people who have participated in working together to combat the novel coronavirus.

\section{CONCLUSION}

The researcher concludes the point of Gan Kim Yong's speech is to provide sufficient information about the 2019 novel coronavirus to Singaporeans. Furthermore, each category of speech acts at this speech is related one to another. It is known that Gan Kim Yong as the representative of Singaporean government presents the current conditions relating to coronavirus in representatives utterances, then based on these information government gets the Singaporean to do several things as the measurement to combat the coronavirus in directives utterances. After that, the commissive utterances are delivered to undertake government conducts further policy to face the coronavirus and then at the end, the government appreciates all sides that participate in working together in this period. However, there is a big difference in 
total utterances from representatives to the other categories. Then the researcher considers that it is better to arrange the utterances in functional proportional categories or the difference of the amount is not too far to make it more effective in delivering the point of the speech.

\section{REFERENCES}

Austin, J. L. (1962). How to Do Things with Words. New York: Oxford University Press.

Diamond, A.S. (1959). The History and Origin of Language. London: Metheun and Co. Ltd

Pei, Mario. (1964). Voices of ManThe Meaning and Function of Language. London: George Allen and Union Ltd.

Richards, J.C. \& Schmidt, R. (2002). Longman Dictionary of Language Teaching and Applied Linguistic. New York: Longman.

Finch, G. (2000). Linguistic Terms and Concept. New York: Palgrave Macmillan.

Searle, J. R. (1969). Speech Acts. Cambridge: Cambridge University Press.
Flowerdew, J. (2013). Discourse in English Language Education. New York: Routledge Taylor and Francis Group.

Dylgjeri, A. (2017). Analysis of Speech Acts in Political Speeches. European Journal of Social Sciences Studies. Volume 2, Issue 2.

Hashim, S.S.M. (2015). Speech Acts in Political Speeches. Journal of Modern Education Review. Volume 5, No. 7, pp. 699-706.

Akinwotu, S.A. (2013). A Speech Act Analysis of the Acceptance of Nomination Speeches of Chief Obafemi Awolowo and Chief M.K.O. Abiola. English Linguistics Research. Volume. 2, No. 1.

Searle, J. R. (1969). Speech Acts. Cambridge: Cambridge University Press.

Searle, J. (1976). The classification of illocutionary acts. Language and Society.

Kreidler, C.W. (1998). Introducing English Semantics. London: Routledge.

Yule, G. (1996). Pragmatics. Oxford: Oxford University Press.

Budd, R. W., Thorp, R. K., \& Donohew, L. (1967). Content Analysis of Communications. New York: Macmillan. 
Lindkvist, K. (1981). Approaches to Textual Analysis. In K. E. Rosengren (Ed.), Advances in content analysis. Beverly Hills, CA: Sage.

Tesch, R. (1990). Qualitative research: Analysis Types and Software Tools. Bristol, PA: Falmer 